\title{
THE COMPREHENSIVE APPROACH CONCEPT IN MULTINATIONAL OPERATIONS
}

\author{
Mihai-Marcel NEAG \\ "Nicolae Bălcescu” Land Forces Academy, Sibiu, Romania \\ mmneag@yahoo.com \\ Lucian ISPAS \\ "Nicolae Bălcescu” Land Forces Academy, Sibiu, Romania \\ ispaslucian04@yahoo.com \\ Cătălin GRINDEANU \\ “Nicolae Bălcescu” Land Forces Academy, Sibiu, Romania \\ grindeanucatalin@yahoo.com
}

\begin{abstract}
The planning of operations is regulated by documents covering the participation of forces in military actions in a national and multinational context. The process of planning the operations has been adapted to conceptual planning progress. The concept of allied effect-based operations, which was an alternative to old national concepts, has undergone transformations, so the process of planning operations at allied level is currently based on the concept of a comprehensive approach, which is a strategic concept, do not give up effects. The term action-based operations has been replaced by the term "thought-based thinking" and belongs to the general concept of comprehensive approach. If the planning process meant the effects, so the main planning objectives were the effects, then the planning was based on concrete objectives, the effects being maintained for the economy of effort and maximizing efficiency, the main purpose of the effects being the evaluation of the operations. From this point of view, we consider that the concept has not been abandoned, what has changed, it was just the working method, the subject being still topical.
\end{abstract}

KEYWORDS: comprehensive approach, civil - military relations, operations based on effects

\section{Introduction}

The Comprehensive Approach (CA) is a more and more common expression in the specific language of counter-insurgency or crisis management and conflict prevention, both at the level of states and at the level of international organizations (UN, NATO, EU, etc.). However, despite the frequent use of the term, there is no common understanding of the role and mode of manifestation in its multinational environment, with a multitude of interpretations and understandings, depending on the actors that use it or the subject of security at issue.

In the military actions carried out in a multinational operational environment, the way in which the concept of comprehensive 
approach is understood has direct effects both on the choice of working tools and the application of appropriate measures to the crisis or conflict situation and on the way of organizing the training and education process at the level of military and civilian personnel involved in solving the problems specific to the operation area. This fact leads us to deepen the study of the concept, going beyond the general perspectives that define the comprehensive approach through - the relationships between the military and civilian actors involved in the stabilization of areas in crisis or conflict.

\section{The Emergence of a} Comprehensive Approach Concept

According to some authors, the concept of comprehensive approach can determine the beginnings when the economic problems of the war have generated on the part of the military structures and the diplomatic structures an increased interest in strengthening and improving the relations between them. Military specialists believe that at the heart of the concept is the same great thinker and military strategist - Carl von Clausewitz who emphasized the importance of ensuring a stable unity in the government-armypopulation triangle (Wendling, 2017).

In our view, the comprehensive approach has indeed begun to have a conceptual relevance with the Cold War when there have been major concerns both at Member State level and at the level of international security organizations for maintaining and strengthening NATO's status, in the context of the effects of the disappearance of the USSR and the conclusion of the bipolar confrontation.

These concerns materialized for the first time in the form of a joint action plan at the NATO Summit in Bucharest (2008). This plan identifies four areas of activity to integrate the concept of comprehensive approach: 1. planning and conducting operations; 2. lessons learned, training, education and exercises; 3. Strengthening cooperation with external actors; 4 public communication NATO International Staff (C-M(2008)0029-COR1). Following the Lisbon Summit, the action plan for implementing the comprehensive approach concept has been updated and completed, generating an integrated matrix of action areas that can deliver increased Alliance efficiency, in line with the comprehensive approach concept.

Thus, the Lisbon Strategic Concept (2010), summing up the concerns of NATO member states so far, highlights the importance of making Alliance actions more efficient by addressing civil, military and civilian issues in crisis management (NATO, 2010) and sets the beginning of a new stage on how to engagement of NATO capabilities in the operational environment - the step of the comprehensive approach.

3. Factors that Contributed to the Emergence and Development of the Concept of Comprehensive Approach

The main theoretical landmark that contributed to the emergence and development of the concept of comprehensive approach is represented by civil - military relations. Civil-military interaction in support of stability operations is understood and applied differently by the UN, NATO and the EU. The Civil-Military Cooperation (CIMIC) concept describes civilian-military relations through "the coordination and cooperative action in support of the mission between NATO commander and civilian actors, including both the population and the authorities local and international, national and nongovernmental organizations and agencies" (NATO, 2008). The EU uses the term CivilMilitary Coordination (CMCO) in a NATO-like understanding but pays more attention to civilian capabilities. The UN has institutionalized civil-military relations, and has two departments: the United Nations Office for the Coordination of 
Humanitarian Affairs (OCHA), which manages civilian-military relations in the field of humanitarian operations and the Department for Peacekeeping Operations (DPKO) for civilian-military relations in peacekeeping missions. The analysis of civil-military relations from the perspective of the UN, the EU, NATO has created the opportunity for international development of the CIMIC concept in its specific forms for each security organization (OCHA: CMCoord (Civil-Military Coordination), DPKO: UN - CIMIC (Civil-Military Coordination) EU: CIMIC (EU-CIMIC). The CIMIC concept is based primarily on the coherent action of all actors civilian and military personnel from the operations area to support the mission of the military commander or civilian authority. If the CIMIC concept supports the mission, the concept of a comprehensive approach supports the intention.

From a military perspective, the concept of comprehensive approach originates in the doctrines and manuals presenting the practical ways of systemic analysis of the modern combat space. The US has developed the concept of Effects Based Operations (EBO) trying to keep and use at maximum the strategic advantage of technological and informational capabilities in the continuous spectrum of the peace-war-the new peace. EBO makes the move from the concept of "weapons against targets" to the concept of "conceived actions of dominating the opponent" by understanding the behavior of their own forces, neutral actors and opponents in time of peace, crisis and war (Smith, 2002). Through the EBO concept, the United States unifies civilian-military actions, joining the central ideas of planning and executing kinetic military operations (destroying key targets, opponent wear, etc.) and ideas that offered the possibility of non-kinetic military engagement with the aim of strengthening cohesion and aggregation of national political, economic and military efforts. Thus, EBO philosophy proposed two ways of action in the process of making the armed struggle more efficient: 1. concentrating its own efforts for destroying the will to fight the enemy (the desired result - limiting to the maximum the kinetic engagement in the fight); 2. Expanding the application of the network-based war concept from the specific military area - the armed struggle to a wider area, the continuing conflict spectrum (peace-war-the new peace).

The NATO version of effects-based operations is the EBAO (Effects Based Approach to Operations) approach. EBAO (Smith-Windstor, 2008) is the coherent and comprehensive application of the various Alliance instruments, along with practical cooperation with non-NATO actors involved in the operations area, to create the necessary effects to meet campaign objectives and reach the planned (desired) end-state. This concept of NATO offers practical organizational framework necessary for a civil-military cooperation effective at all levels (strategic, operational and tactical), the military (armed forces), political (diplomacy), economic (sanctions, aid and investment) and civil society (police and gendarmerie, justice, education, health, public information, civil administration and infrastructure).

Even though they have contributed to the emergence and development of a comprehensive approach, the EBO and EBAO concepts have been focused on analytically and systemically identifying methods and processes to streamline military action rather than civil-military action. Comprehensive elements such as hubs of subconcepts, systems system analysis, critical information plan development, securing decisional superiority, matrix of synchronization of actions and the effects of the operation are difficult to use by civilian actors of NATO member states and/or civilian/military 
partners (non-NATO) for at least two reasons: 1 . the procedures, terminology and tools used require a high level of knowledge that can not be accumulated during the time and space available for the preparation of an operation; 2. The accessibility and transparency of civilian-military actions is restricted by procedures for accessing information (the need to know principle in certain situations and operating environments).

The comprehensive approach attempts to overcome these barriers as well as other issues that influence the EBO or EBAO procedures in correctly determining the effects in the trinomial operational environment (the population-enemy-troop) in which the population element creates contexts difficult to predict.

The current US Doctrine for Ground Forces reduces the EBO's usefulness to the conceptual context by which it can be added to the efficiency of the classical "mission analysis" carried out at each military structure (U.S. JOINT Force Command, 2008): 1. better understanding of the operating environment is by knowing the culture and the history of the conflictaffected society by identifying the specificities of the interactions between the military structures and other governmental and non-governmental organizations in the area of action by analyzing the economic and political functioning, as well as by analyzing other factors that contribute to increasing efficiency military 2. visualization of the master's intention through the desired effects, ensures the unit of action (the principle of order centralization and the decentralization of the execution); 3 . how to target targets (criteria for target selection); 4. progress analyzes (periodic checks on the established objective relationship - result obtained and measures accordingly).

National approaches seek to harmonize actions at the level of its ministries, departments and agencies in the three important areas of defense, foreign affairs and international development, with the ultimate aim of making it more effective to promote and defend the vital values and interests of national states.

The National Defense Strategy of Romania, referring to the way of securing national security and defense in the unpredictability of the crisis and conflicts evolution on the international scene, describes the necessity of a multidimensional strategy ("approach"): "The strategy has an integrated and multidimensional approach, in which the defense dimension combines and balances with a number of other dimensions - public order; intelligence, counterinformation and security; diplomacy; crisis management; education, health and demography" (Administratia Prezidenţială, 2015, p. 5).

Also, the comprehensive approach is a subject also touched upon in the Romanian Army Doctrine. In the subchapter "Contribution of the Romanian Armed Forces to the Comprehensive Approach", it is stressed the need for a comprehensive approach of the international community in the contemporary problem of crises, requiring "coordinated actions of a diverse range of military and civilian actors, assured through deconflictalization of political actions and NATO military and those of the other instruments of power" (SMG, 2012).

Based on the above, the comprehensive approach is a process of interpreting and deciphering all interests in an operating environment to apply civilianmilitary capabilities that resonate with the de facto truth of the crisis situation and/or conflict, for which specific political objectives have been determined.

\section{Approach}

4. Principles of Comprehensive

The Comprehensive Approach (CA) is based on the following guideline guidelines: ensuring the unit of action (however it has been called: command unit, effort unit, goal unit, etc); the tools at their 
disposal (diplomatic, economic, military, informational, psychological, social, etc.); political objectives. The three landmarks are integrated today in the UN, NATO and EU statements on comprehensive security issues.

The experience gained by the Alliance in the theaters of operations in the Balkans and Afghanistan has shown that resolving problems in the crisis or conflict area is not just about applying the means of the military forces with justice, nor about the individual, impartial and independent involvement of other agencies or organizations international security, but by the efficient and coherent working of all actors involved - generically called - the comprehensive approach. The comprehensive approach to contemporary crises ensures, in an orchestrated manner, convergent actions to achieve the objectives at each decision level, as follows:

- political and strategic levels: strengthening mutual trust and understanding among international actors;

- operational level: supporting the civilmilitary interaction of the international actors involved in the planning and management of operations;

- tactical level: authorizing tactical force commanders to carry out independent actions of cooperation and coordination with local authorities and international actors in the area of responsibility in support of the good execution of the operation.

NATO experts believe that the prerequisites for successful fulfillment of these objectives lie in the following actions: to increase the internal coherence of planning proced with international, governmental, nongovernmental and local organizations during the planning ures at political and military levels, to improve the transparency and cooperation and management of operations, as well as the improvement of military capabilities to carry out activities to support reconstruction and development efforts along with other actors in the operations area.

The activity of harmonizing the activities of all actors involved in the analysis, planning, management and evaluation of interventions in crisis or conflict areas can be facilitated by the following principles (Multinational Interoperability Council, 2011):

- The effort unit. Ensure the convergence of civilian-military actions starting with the initial stages of planning and executing the operation by integrating into the decision-making process national or international power items that can support the achievement of strategic objectives.

- Property right. The planning and execution of a multinational operation in an area of crisis and/or conflict must be based on the leadership, participation and commitment of the country and the host nation. The population of the country in which it intervenes must look at the stability and reconstruction operations carried out by international actors as if it were carried out by itself. The population must be the center of gravity of the actions of agents operating in the international environment, and it must also be the main actor responsible for building a viable peace and stable economies in a crisis and/or conflict area;

- Strengthen local capabilities. The potential of local public and private institutions while managing instability elements must be the objectives of each actor involved in the early stages of the operation;

- Recognize the interdependence between policy-security-development. Failure or lack of results in a specific area of action (political, security, economic, social, etc.) can generate chain reactions that lead to failure in all actions; 
- Achieving long-term goals is achieved with short-term results. Experience has shown that the lack of visible results in the short term has generated instability, distrust and uncertainty among the affected population. Taking measures to meet the essential needs of the affected population contributes to the stabilization of the security environment and ensures the possibility of pursuing long-term development strategies;

- Flexibility - learns and adapts permanently. The analyzes and actions of the actors involved must be calibrated in accordance with the circumstances and particularities of the operation area. In such an operational environment, the only constant process of planning is change;

- Adopt a proactive attitude. Proactive and non-reactive attitude may reduce the risk of future escalation of the crisis or conflict;

- Support objectives with sufficient and safe resources. A frequent cause of failure to perform missions in Stability and Reconstruction operations is related to the insufficient allocation of human and material resources;

- Focus on eliminating sources of instability and conflict causes. Scheduling and action programs in Stability and Reconstruction operations should focus on activities that can lead to the reduction of agents causing instability on the one hand and on ways to strengthen local institutional capabilities to be able to deal with, transparent and responsible for the problems of its communities on the other.

\section{Conclusions}

In trying to identify the meaning of the concept of comprehensive approach and how to apply it to multinational operations, we have found that although the concept of comprehensive approach is more and more common in the specific language of counterinsurgency or crisis management and conflict prevention, (UN, NATO, EU, etc.), yet it has failed to be defined and understood in a unitary way, with a multitude of interpretations and understandings depending on the actors involved or on the subject of security in question.

However, the emergence and development of the concept of comprehensive approach had as the main propulsion engine the relations established between the civil structures and the military structures committed to the effective implementation of the diplomatic, economic, military and other diplomatic power instruments for the fulfillment of the political objectives desired. Thus, we have come to the conclusion that if, in the spirit of the known concept - CIMIC - the civilmilitary actions are directed to the mission (military objectives), in the spirit of the concept of comprehensive approach, civilmilitary actions have gained a more qualitative understanding high, being directed to the fulfillment of the intent (political objectives). By this fact, the comprehensive approach succeeds in making the integrated civil-military action more efficient by emphasizing the importance of achieving the effects according to the intent, which, having a political foundation, always ensures the possibility of applying military solutions with more creativity.

In the light of the above, we believe that the use of the concept of comprehensive approach must be understood by the fact that it represents the process of interpreting and deciphering all the interests that manifest in an operating environment in order to apply the civilmilitary capacities resonating with the de facto truth the crisis situation and/or conflict, for which specific political objectives have been determined. 


\section{REFERENCES}

Administraţia Prezidenţială. (2015). Strategia naţională de apărare a ţării pentru perioada 2015-2019. O Românie puternică în Europa şi în lume, Bucureşti.

C-M(2008)0029-COR1. (2008). Political Affairs \& Security Policy, Comprehensive Approach Action Plan, 1-4 - 1-8.

Multinational Interoperability Council. (2011). Coalition Building Guide- $2^{\text {nd }}$ edition, Policy and Doctrine Multinational Interoperability Working Group, September 2011, 2-3.

North Atlantic Treaty Organization. (2008). Bucharest Summit Declaration Issued by the Heads of State and Government participating in the meeting of the North Atlantic Council in Bucharest on 3 April 2008, available at: http://www.summitbucharest.ro/en/doc 201.html, accesed on 25.03.2017.

North Atlantic Treaty Organization. (2010). Strategic Concept for the Defence and Security of the Members of the North Atlantic Treaty Organisation, Brussels: NATO Public Diplomacy Division, 6.

Smith, E. A. (2002). Effects Based Operations - Applying Network Centric Warfare in Peace, Crisis, and War, CCCR Publications Series, available at: http://www.au. af.mil/au/awc/awcgate/ccrp/ebo smith.pdf, 108.

Smith-Windstor, B. (2008). NATO's Effects Based and Comprehensive Approach to Operations, NATO Defence College Research Paper no. 38, 2.

Statul Major General (SMG). (2012). Doctrina Armatei României, București: Editura Centrului Tehnic-Editorial al Armatei.

U.S. JOINT Force Command. (2008). Assessment of Effects Based Operations, Norfolk: Author, 5-6.

Wendling, C. (2017). The comprehensive approach to civil-military crisis management. a critical analysis and perspective, available at: http://www.mo.gov.si/ fileadmin/mo.gov.si/cfs/ Literatura/SIMIBBook.pdf, 19. 